Bangladesh J. Bot. 37(2): 105-114, 2008 (December)

\title{
MORPHOLOGY AND ANATOMY OF ENDEMIC THERMOPSIS TURCICA KIT TAN, VURAL \& KÜÇÜKÖDÜK
}

\author{
Canan ÖZdemiR*, Hüseyin Dural ${ }^{1}$, Kuddisi ErtuĞRul ${ }^{1}$, Mustafa KüÇüKÖDÜK ${ }^{1}$, \\ Pelin Baran AND M. Aydin ŞANDA ${ }^{1}$ \\ Department of Biology, Faculty of Art and Science, \\ Celal Bayar University, Manisa/Turkey
}

Key words: Leguminosae, Thermopsis turcica, Morphology, Anatomy

\begin{abstract}
Morphology and anatomy of an endemic plant from Turkey, Thermopsis turcica Kit Tan, Vural \& Küçüködük, belonging to Fabaceae have been investigated. The species had a perennial rhizome, an erect stem and compound leaves consisting of three leaflets. Morphological and anatomical research findings have been presented by photographs, drawings and tables.
\end{abstract}

\section{Introduction}

The family Leguminosae is divided into three subfamilies Papilionoideae (=Faboideae), Mimosoideae and Caesalpinoideae (Davis 1969). Most of the tropical Faboids are woody, while those out of tropics are usually herbaceous (Baytop 1991). Traditionally, the small tribe Thermopsideae of Faboideae includes 6 genera scattered through the Mediterranean basin and central to North-East Asia. The tribe as a whole is absent from the southern Hemisphere. The genus Thermopsis contains perennial herbs producing rhizomes (Wang et al. 2006). Thermopsis is a genus of about 25 species distributed in Asia and North-America, mostly in montane regions (Davis et al. 1988). Based on nuclear ribosomal DNA analysis, the tribe Thermopsideae is phylogenetically not a monophyletic group. The East Asian and North-American disjunct Thermopsis species are not monophyletic. According to the DNA analysis, there is a geographical division between the old world and the new world Thermopsis (Wang et al. 2006).

Thermopsis turcica is an endemic perennial herb with large rhizome in East Mediterranean region. Thermopsis is a genus confined to Central Asia and East United States, and it is represented by only one endemic species, $T$. turcica in Turkey. The unique character of $T$. turcica is the uniform occurrence of three free carpels. The polycarpellary condition of $T$. turcica is a clearly derived, rather than a primitive character since the whole Papilionoid pollination syndrome has obviously evolved around the presence of a single median carpel (Davis et al. 1988, Kit et al. 1983). Although presence of polycarpellary condition has been previously documented in normal members of the Mimosoideae and Caesalpinoideae, apart from teratological forms, this is the first record in the Faboideae (Kit et al. 1983).

There have been a number of morphological, anatomical and phylogenetic studies of the subfamily Faboideae (Aniszewski et al. 2006, Wang et al. 2006, Yiotis et al. 2006, Oliveira and Paiva 2005, Ainouche et al. 2003, Doyle et al. 2000, Ainouche and Bayar 1999, Pereira-Netto et al. 1999, Talavera and Gibbs 1997 and Crow et al. 1997).

\footnotetext{
*Corresponding author. E-mail: <cozdemir13@gmail.com><pelinbaran@gmail.com> ${ }^{1}$ Department of
} Biology, Faculty of Art and Science, Selcuk University, Selçuklu/Konya/Turkey. 
The literature searching of Thermopsis revealed that there has been no anatomical study. Investigations have been performed on the chemical constituents of Thermopsis species (Asilbekova 2004, Kotenko et al. 2001). Apart from the morphological description of T. turcica (Kit et al. 1983), there has been only one study on the alkaloids of the species (Rahman et al. 1991).

It is reported that some Thermopsis species contain alkaloids, flavanoids, vitamin C, macroand microelements. The air-dried aerial part is used as a medicinal raw material for a cytisine preparation and as an expectorant (Asilbekova 2004, Kotenko et al. 2001). On the other hand, the genus Thermopsis consists of poisonous and harmful species with low feeding value (Li 1997, Zhang and Lui 1996). Thermopsis species have been suspected of causing livestock losses. In addition, series of human poisoning by Thermopsis has been reported. Twenty three suspected cases of Thermopsis exposures, some resulting in significant toxicity like vomiting, abdominal pain, drowsiness, oral irritation, tachycardia, tremors and other general symptoms are reported (Mcgrath-Hill and Vicas 1997). Some Thermopsis are also used as ornamentals in the United States (Lockhart 2005).

Since there is no report on the anatomical features of Thermopsis, morphological and anatomical characters of a Turkish endemic, T. turcica have been reported here in detail.

\section{Material and Methods}

Plant samples were collected from natural populations at the following location:

B3: Konya, Akşehir, Gölçayir Village, Lake sides, 960m, 28.05.2004 (Küçüködük 1251).

Taxonomic description of the plants was done according to Kit et al. (1983) and Davis et al. (1988). Anatomical studies were carried out on the samples kept in $70 \%$ alcohol and using paraffin method (Algan 1981). The cross-sections were also taken by hand using razor blade. Results were presented by photographs, drawings and tables.

\section{Results and Discussion}

Morphological features

T. turcica is a perennial herb with long rhizome. Erect stem up to $35-80 \mathrm{~cm}$ in length and densely white-villous in the upper parts. Sterile branches leafy, striate, sheathing at the base. Sheaths scarious, passing into leaf-like stipules. Leaves alternate, digitately trifoliolate, whitesericeous or sometimes white-villous, becoming greyish-green. Stipules leaf-like, free, those on the main stem much larger than those at the leaf bases, acute. Petioles $07-2.5 \mathrm{~cm}$ in length. Leaflets elliptic-ovate, $11-40 \times 4-16 \mathrm{~mm}$ in dimension, acute, densely white-villous on both surfaces. Inflorescence terminal, racemose, $12-35 \mathrm{~cm}$. Flowers large, bracteate, zygomorphic, hermaphrodite. Bracts leaf-like, ovate, $7-15 \times 3-11 \mathrm{~mm}$, white-villous, the margins long-ciliate. Pedicels up to $24 \mathrm{~mm}$. Calyx $9-13 \mathrm{~mm}$ in length, densely white-villous, unequally 5 -toothed, bilabiate, the upper lip forming 2 teeth of ca. $6 \times 8 \mathrm{~mm}$, the obtuse lobe sometimes cleft to 1.4 $\mathrm{mm}$; the lower lip forming 3 teeth, nearly equal, triangular-acute, $4.5-5.5 \times 2.5-3.0 \mathrm{~mm}$ in dimension. Petals golden yellow in colour, imbricate, free except for partly connivent keels. Standard glabrous, $25 \mathrm{~mm}$ with a $5 \mathrm{~mm}$ claw and suborbicular, the retuse lamina ca. $20 \times 25 \mathrm{~mm}$, the wings glabrous, $2 \times 9 \mathrm{~mm}$ (inc. $1.8 \mathrm{~mm}$ claw), the keel ca. $22 \times 8 \mathrm{~mm}$ (inc. $7 \mathrm{~mm}$ claw) in dimension being dorsally coherent. Stamens 10 and free. Filaments filiform, not dilated, 18-20 $\mathrm{mm}$ in length, glabrous; anthers uniform, dorsifixed, $1.8 \mathrm{~mm}$ in length, yellow in colour. Disc 
absent. Ovary 3-carpellate, carpels free, each 1-locular, nonseptate, white-villous, sessile; ovules 10 in number and on the adaxial suture; style ca. $12-13 \mathrm{~mm}$, glabrous, recurved at apex, persistent in fruit; stigma terminal, small and capitate. Fruit a legume, 2-3 seeded, elliptic- or oblong-ovoid, $22-25 \times 7-9 \mathrm{~mm}$ in dimension, slightly falcate, nearly straight at maturity, densely sericeus-villous, indehiscent. Seeds exarillate, subreniform in shape, 3.5-5 × 2.5-3 mm, smooth, not foveolate, pale purplish. Grows in marshy lakeside ca. 950-1050 $\mathrm{m}$ in altitude (Pl. 1).

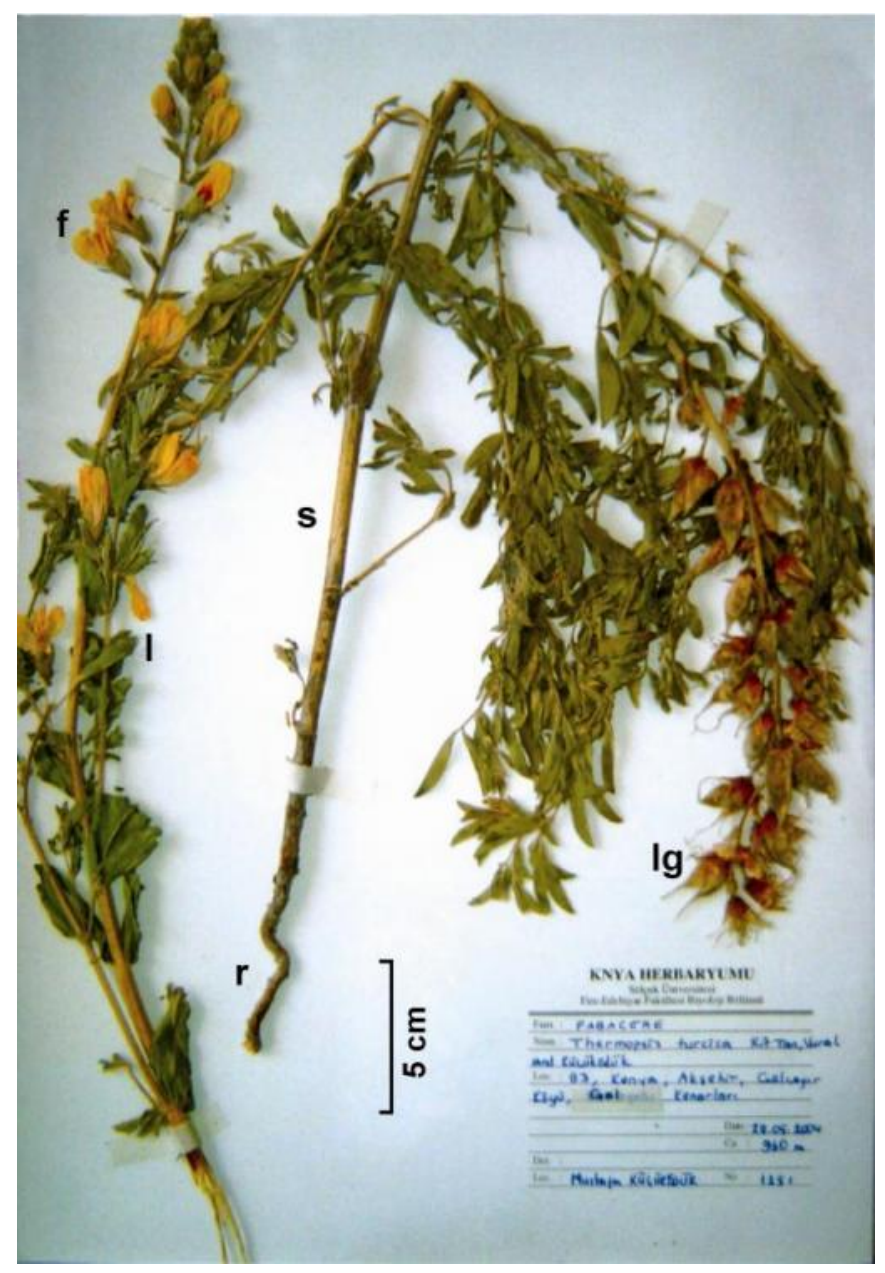

Colour

Plate 1. General appearance of Thermopsis turcica Kit Tan, Vural \& Küçüködük.

f. flower, s. stem, lg. legume, 1. leaf and r. root.

Anatomical characteristics

Root: The outer surface of the root was covered by 3 - 5 layered periderm of which cells were dark coloured, crushed, broken up and sometimes fallen out. Cortex was $8-24$ layered below the peridermis. Large or small sclerechyma groups were located on the well-developed phloem. Trachea cells were irregularly located in the xylem tissue that was below the phloem. Pith rays were 1 - 5-layered. A great number of pith rays, 1 - 2-layered were close together in the xylem tissue. The center of the root was filled up with parenchymatous pith cells (Pl. 2 A, B). 


\begin{tabular}{|l|}
\hline Colour \\
Fig. A
\end{tabular}
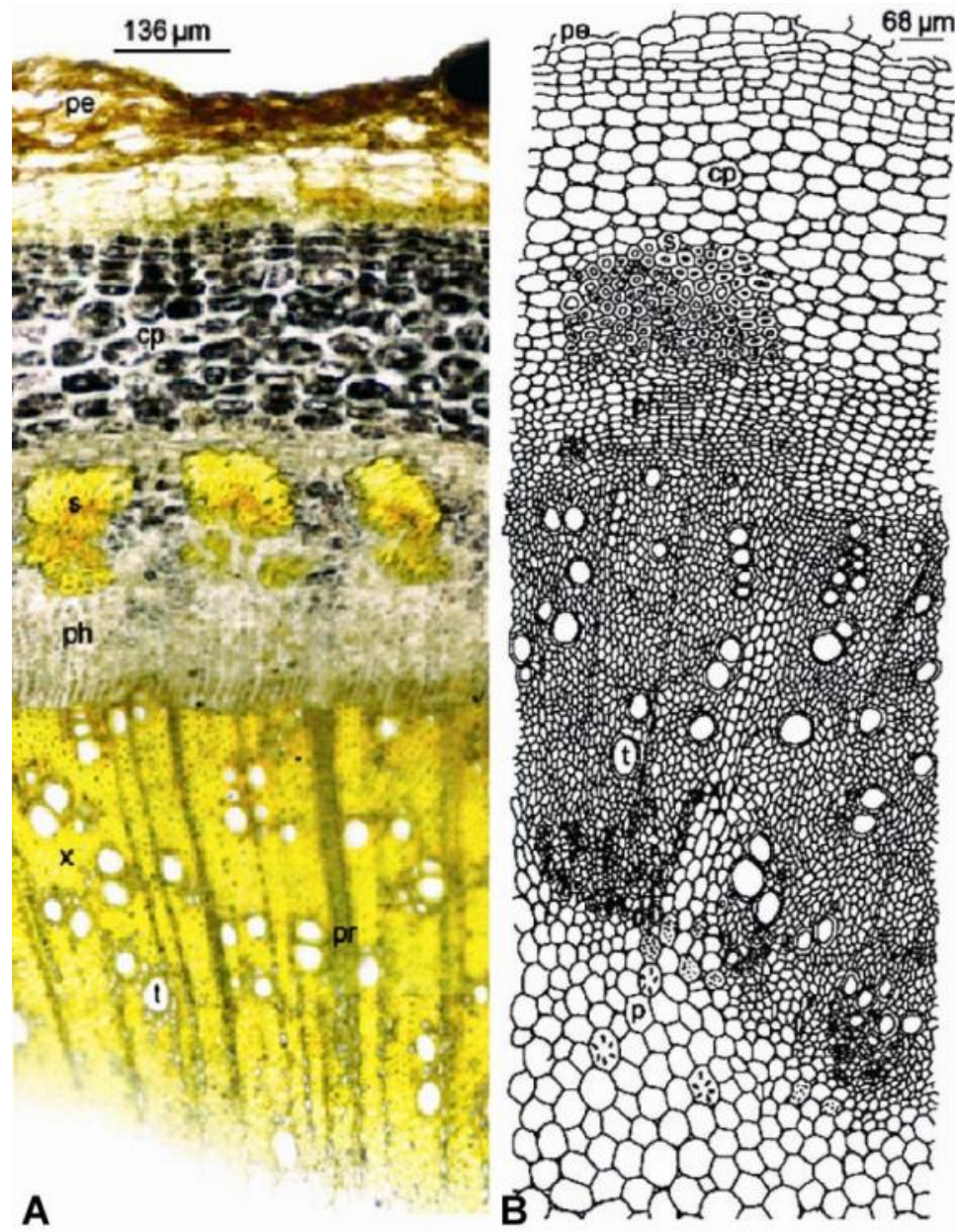

Plate 2. Cross-sections of root of Thermopsis turcica. A. Microphotograph. B. Camera Lucida drawing. pe: peridermis, ph: phloem, t: trachea, p: pith, cp: cortex parenchyma, pr: pith ray, s: sclerenchyma and x: xylem.

Stem: The cross-section of stem was circular or sometimes angular and nearly quadrangular. The outer surface of the cross-sections was slightly wavy exhibiting small, thin projections. A thick cuticle was present on the epidermal cells of which shape was quadrangular or rectangular. 1 - 5 layered collenchyma was located below the single layered epidermis. Parenchymatous cortex was present under epidermis which was 4 - 16 layered. Vascular bundles consisted of xylem, phloem and sclerenchyma patches. Sclerenchyma patches surrounding the phloem were 2 - 5 layered. The thick-walled cells forming sclerenchyma patches upon the phloem tissue were noticeably large, nearly as much as the size of the trachea. Phloem elements were clear. Cambium was 3 - 4 layered in woody stem, but indistinctive in young stem. Trachea and tracheids were arranged in regular rows. A large cavity was present at the middle of pith region. This cavity was formed by the broken parenchymatic cells that were thin-walled. Starch grains were frequently present in the parenchymatous pith cells (Pl. $3 \mathrm{~A}, \mathrm{~B}, \mathrm{C}, \mathrm{D})$. 
Petiole: Epidermis was 2-layered. A thick cuticle was present on the epidermal cells. 4-14 layered parenchyma was located between the epidermis and the vascular bundles. There was a very large, undivided vascular bundle at the center and one small bundle at both ends of the petiole. Phloem tissue was clear under the sclerenchyma patches. Trachea cells were regularly arranged in the xylem tissue. There was a 4-10 layered, thick-walled parenchyma below the xylem tissue, apart from other parenchymatous cells under the epidermis (Pl. 4 A,B).

\begin{tabular}{|l|}
\hline Colour \\
Fig. A \\
\hline
\end{tabular}

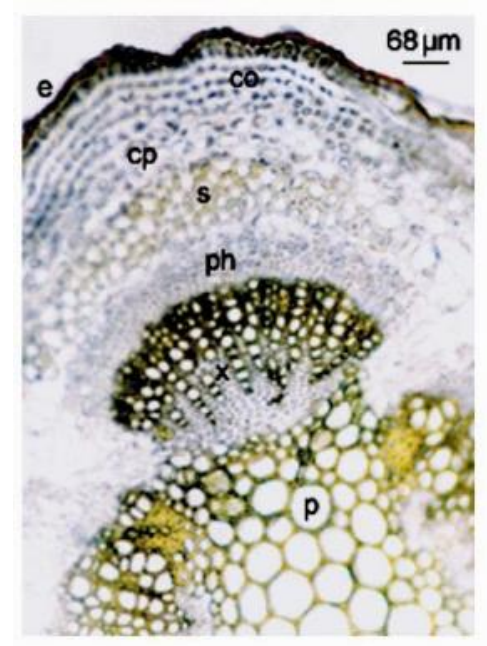

A

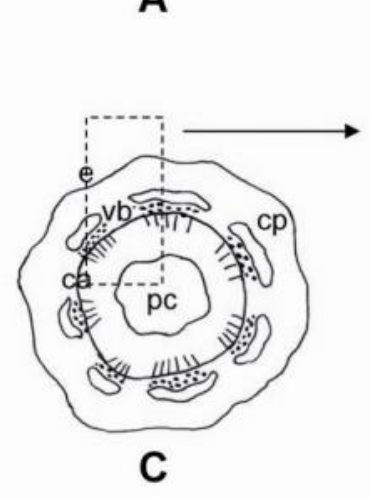

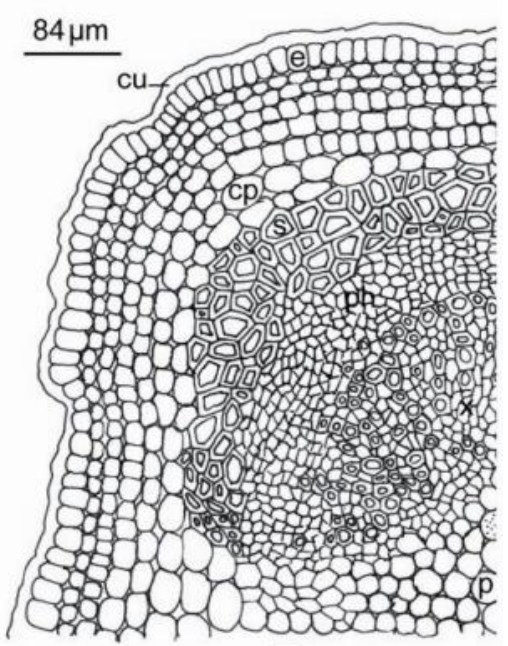

B

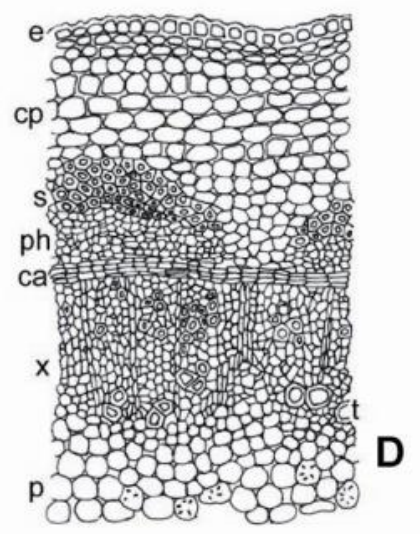

Plate 3. Cross-sections of young (A, B) and woody (C, D) stems of Thermopsis turcica. A. Microphotograph. B, C and D Camera Lucida drawing. e: epidermis, cu: cuticle, vb: vascular bundle, ph: phloem, t: trachea, p: pith, pc: pith cavity, cp: cortex parenchyma, co: collenchyma, ca: cambium, s: sclerenchyma and $\mathrm{x}$ : xylem

Leaf: A thick cuticle was present on both abaxial and adaxial epidermis of leaf, being the thickest on the abaxial epidermal cells where the median vein was located. In contrast to the epidermal cells where the median vein was located, of which length size was longer than the width size, epidermis cells located at the other parts had usually longer width than the length size. Stoma cells were located at the adaxial and abaxial epidermis, being at the same line with epidermal cells. Capitate glandular hairs with or without stalk cells were scarcely present near eglandular hairs. 
Although mesophyll was not clearly differentiated as palisade and spongy parenchyma, it was formed by 2 - 3-layered palisade parenchyma under both adaxial and abaxial epidermis and 12-layered spongy parenchyma hardly visible at the median part between them.
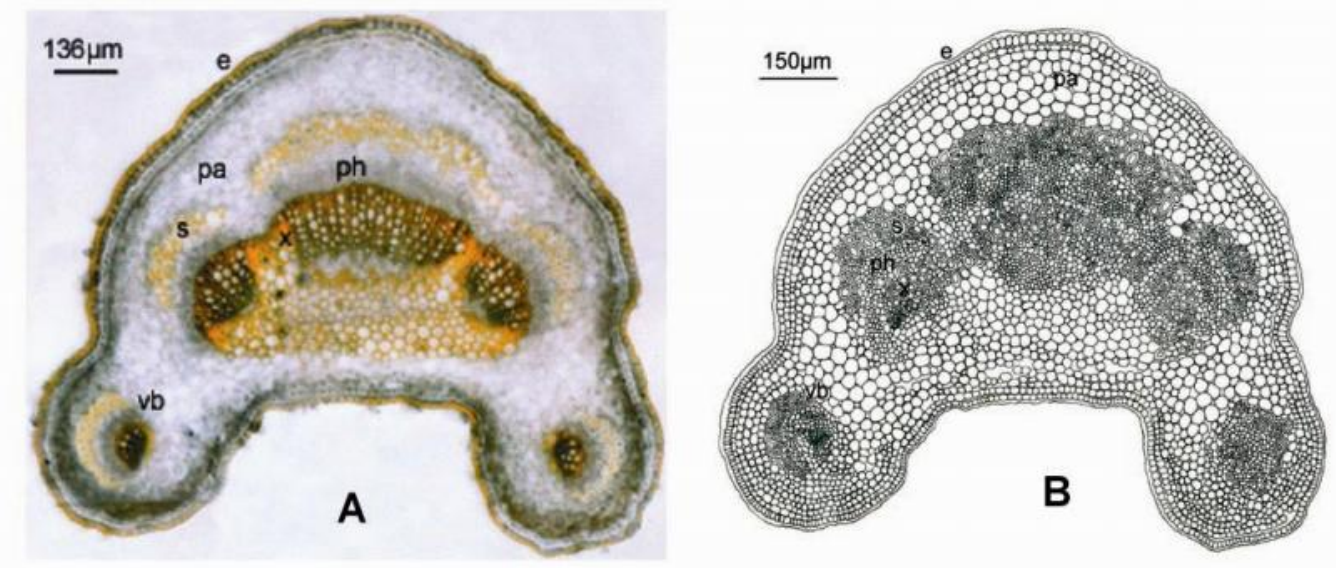

Plate 4. Cross-sections of petiole of T. turcica. A. Microphotograph. B. Camera Lucida drawing. e: epidermis, ph: phloem, pa: parenchyma, vb: vascular bundle, s: sclerenchyma and x: xylem.

Mesophyll cells were with chloroplasts. Smaller vascular bundles in leaf were surrounded by 1-layered parenchyma of round shaped cells without chloroplasts. Vascular bundles forming the median vein were surrounded by round-shaped parenchyma cells mostly without chloroplasts (PI. $5 \mathrm{~A}, \mathrm{~B})$.

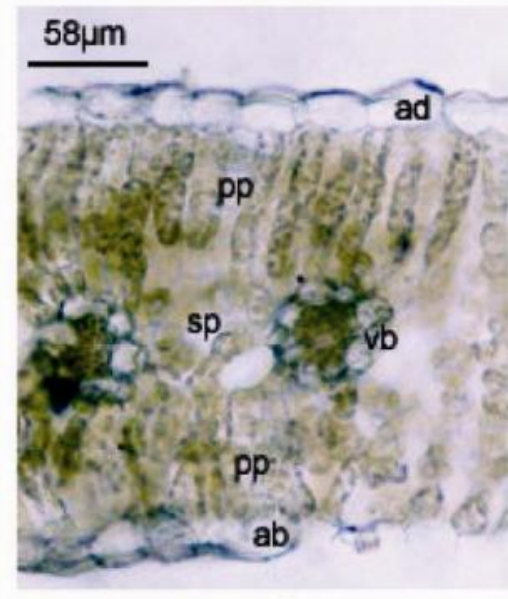

A

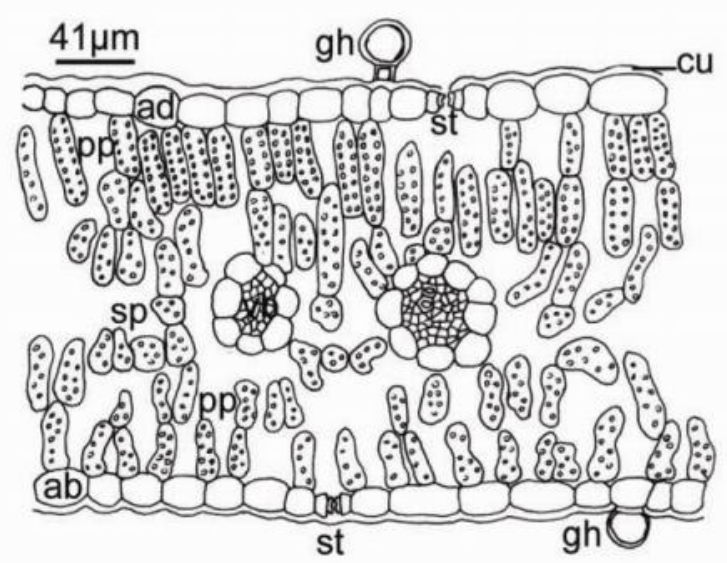

B

Plate 5. Cross-sections of leaf of Thermopsis turcica. A. Microphotograph. B. Camera Lucida drawing. ad: adaxial epidermis, ab: abaxial epidermis, cu: cuticle, pp: palisade parenchyma, sp: spongy parenchyma, vb: vascular bundle, gh: glandular hair and st: stoma cell.

Seed: In the anatomical sections, seed was composed of exotesta, mesotesta and endosperm. There was a thick cuticular layer on the surface of exotesta. Thickness of cuticle was 5.4-16.6 $\mu \mathrm{m}$. 
Exotesta consisted of thick-walled macrosclereids which were longitudinally elongated. Macrosclereids were 96.4-128.6 $\times$ 5.4-26.6 $\mu \mathrm{m}$ in dimension. This tissue was connected to mesotesta layer which consisted of thin-walled parenchymatous cells with intercellular spaces. Mesotesta was 2-layered. One layer was formed by large, semicircular or hourglass-shaped cells and the other was formed by much flattened cells. The compression of the mesotestal layers was clear. Endosperm had dense starch and fat cells and intercellular spaces (Pl. 6).

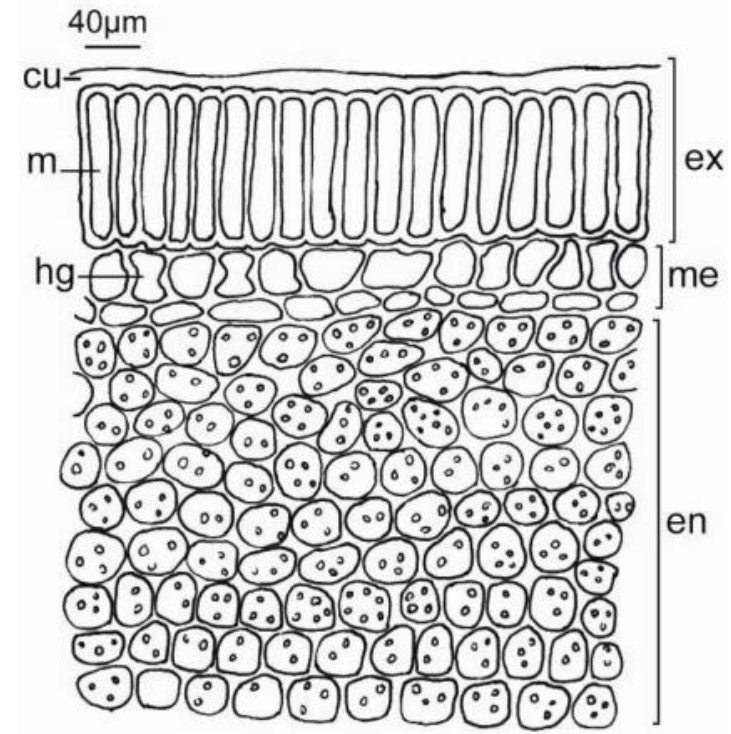

Plate 6. Cross-section of seed of T. turcica. cu: cuticle, m: macrosclereid cell, hg: hourglass cell, ex: exotesta layer, me: mesotesta layer and en: endosperm.

The anatomical characters of T. turcica that have been investigated, have some differences or similarities with some other members of the family. The stem of Calicotome villosa (Poiret) Link. (Leguminosae) is characterized by raised ridges and grooves (Yiotis et al. 2006). Vascular bundles of Cytisus species (Papilionoideae) form ribs on the stem surface (Talavera and Gibbs 1997). Although the stem ribs were absent in T. turcica, the epidermal cells which were accompanied by the cortex parenchyma cells formed a wavy stem surface. A thick cuticle was present on the wavy stem surface.

C. villosa leaves possess stomata on both sides, the abaxial and the adaxial. Leaf is furnished with palisade parenchyma on both sides (Yiotis et al. 2006). The leaflet of Pueraria lobata Willd. a member of Leguminosae, has two layers of palisade parenchyma and one layer of spongy parenchyma (Pereira-Netto et al. 1999). Leaves of T. montana have well-developed palisade and spongy parenchyma (Myers et al. 1997). Although there is a well-developed palisade parenchyma under the adaxial and the abaxial epidermis in T. turcica, the spongy parenchyma in the middle of the mesophyll has hardly been seen between the two palisade parenchyma. Stoma cells were present on both sides of the leaf of T. turcica. A thick cuticle was present on the epidermal cells. The vascular bundles of the leaf were surrounded by round-shaped mesophyll cells without chloroplasts.

There are some reports on the optical properties of Thermopsis leaves in the literature. Martin et al. (1991) investigated the lens properties of the leaf epidermal cells of T. montana. They found epidermis could concentrate light within the leaf amounting well in excess of ambient light 
(Martin et al. 1991). It is reported that the spongy mesophyll is important in increasing internal reflectance of the leaves. The greater proportion of spongy parenchyma in leaves increases intercellular light scattering and thus absorbance (Delucia et al. 1996). It is also reported that the palisade tissue may help in distributing light more uniformly to chloroplasts within leaf (Vogelmann and Martin 1993). The leaves of T. turcica had a greater proportion of palisade parenchyma, being located under the two epidermal layers. This leaf character of $T$. turcica may be the result of an environmental effect like the habitat of the species.

Table 1. Anatomical measurement values of various tissues of Thermopsis turcica.

\begin{tabular}{lllll}
\hline & \multicolumn{2}{c}{ Width $(\mu \mathrm{m})$} & \multicolumn{2}{c}{ Length $(\mu \mathrm{m})$} \\
\cline { 2 - 5 } & Min. - Max. & Mean \pm S.D. & Min. - Max. & Mean \pm S.D. \\
\hline Root & & & & \\
Peridermis cell & $13.2-105.9$ & $55.6 \pm 32.1$ & $13.2-47.6$ & $30.0 \pm 13.8$ \\
Parenchyma cell & $26.5-68.8$ & $48.8 \pm 12.9$ & $21.2-50.3$ & $31.5 \pm 9.5$ \\
Trachea cell & $7.9-79.4$ & $41.9 \pm 22.8$ & & \\
Pith cell & $31.8-84.7$ & $59.1 \pm 23.2$ & & \\
Stem & & & & $28.8 \pm 8.9$ \\
Epidermis cell & $13.2-26.5$ & $20.0 \pm 4.8$ & $15.9-42.4$ & \\
Parenchyma & $10.9-65.5$ & $35.1 \pm 21.9$ & $8.2-38.2$ & \\
Trachea cell & $5.3-52.9$ & $31.9 \pm 19.9$ & & $26.9 \pm 8.3$ \\
Pith cell & $13.2-89.9$ & $59.2 \pm 32.6$ & & \\
Petiole & & & & \\
Epidermis & $4.5-24.1$ & $12.6 \pm 7.1$ & $17.0-40.7$ & \\
Parenchyma & $10.2-57.8$ & $32.8 \pm 15.3$ & & $23.9 \pm 6.0$ \\
Trachea cell & $6.8-30.6$ & $19.0 \pm 9.2$ & & \\
Leaf & & & & \\
Cuticle & $2.7-15.3$ & $7.2 \pm 3.1$ & & \\
Adaxial epidermis cell & $21.4-53.6$ & $37.5 \pm 11.6$ & $10.7-32.1$ & \\
Abaxial epidermis cell & $10.7-58.9$ & $33.6 \pm 15.6$ & $7.9-47.6$ & $24.6-53.6$ \\
Palisade cell & $10.7-21.4$ & $14.9 \pm 3.1$ & & \\
Spongy cell & $15.9-37.5$ & $25.4 \pm 6.1$ & & \\
\hline
\end{tabular}

Pollinators typically visit more flowers on the plants with larger floral displays, which should present such attractive plants with significant pollen transport losses. Many-flowered plants with hermaphrodite flowers might reduce the costs of attractiveness by encouraging fewer sequential flower visits by pollinators (Biernaskie and Cartar 2004). T. turcica had a large floral display with their attractive and abundant flowers.

Leguminous plants (Fabaceae) have exotestal seeds. The term 'exotesta' is often used as an equivalent to the outer epidermis of the integument of the legume ovule and it differentiates as a layer of radially elongated macrosclereids, which are commonly called 'Malpighian cells' or palisade cells (Corner 1976, Werker 1997). Generally, two microscopic characters distinghuish the Fabaceae testa: external palisade cells and hourglass cells (Corner 1951). The testa in legumes is usually composed of seven layers: cuticle 'light line' (absent in some legumes), epidermis (Malpighian layer), hypodermis (sclereid layer), parenchyma, remnant layers and endosperm as the deepest testa layer. However, the testa in legumes is highly differentiated and its anatomical structure is species-specific (Werker 1997). The exotesta of the mature seed of Phaseolus lunatus 
is composed of a very thin cuticular layer, sclerenchyma containing a palisade cell layer and crushed cells. The palisade tissue is of exoepidermal sclerenchyma, constructed from large sclereids, 2-3-layered, which are palisade in form, relatively long. The palisade sclereids are connected to a very thin layer of crushed cells or an adhering layer between the exotesta and mesotesta. The mesotesta is composed of two different layers: thin-walled parenchyma cells with a combination of other cell types and a layer of crushed cells. Parenchyma cells of the mesotesta are large, semicircular, hourglass or stirrup-shaped, but elongated (Aniszewski et al. 2006). In contrast to the seed coat of P. lunatus, that of T. turcica had a thick cuticle and 1-layered palisade tissue consisting of macrosclereids. In the seed coat of T. turcica, the mesotesta with two different layers was composed of thin-walled parenchyma cells. The outer layer of mesotesta was formed by semicircular, hourglass or stirrup-shaped mesotestal cells as well as in P. lunatus and the inner layer was formed by flattened cells. No thin layer of crushed cells or an adhering layer between the mesotesta and exotesta of seed coat of T. turcica was observed in this investigation. The exotesta of the seed coat of Pterodon emarginatus presents radially elongated cells which form the palisade layer. In the mature seeds, the subepidermal layer of the testa differentiates into hourglass-cells; the mesotesta presents many intercellular spaces (Oliveira and Paiva 2005). In the seed coat of $T$. turcica, the mesotesta had intercellular spaces as seen in P. emarginatus.

The Rocky Mountains and intermountain regions are populated by the relatively variable and some widespread Thermopsis species in North America (Chen et al. 1994) while the habitat of endemic T. turcica is marshy lakeside of about $950-1050 \mathrm{~m}$ in altitude in Turkey.

The authors aimed to introduce endemic T. turcica, the first record of the genus Thermopsis for Turkey. T. turcica can be used as an ornamental plant, for their large, attractive and golden yellow flowers. Further studies are needed for cultural needs, physiology and possible conservation measures of this important endemic Turkish plant species which has medicinal values.

\section{References}

Ainouche, A. and R.J. Bayar. 1999. Phylogenetic relationships in Lupinus (Fabaceae: Papilionoideae) based on internal transcribed spacer sequences (ITS) of Nnuclear ribosomal DNA. Amer. J. Bot. 86(4): 590-607.

Ainouche, A., R.J. Bayer, P. Cubas and M.T. Misset. 2003. Phylogenetic relationships within tribe Genisteae (Papilionoideae) with special reference to genus Ulex. In: Advances in legume systematics. Part one. Higher level systematics, B. B. Klitgaard and A. Bruneau (Eds.). Royal Botanic Gardens, Kew, pp. 239-252.

Algan, G. 1981. Bitkisel Dokular çin Mikroteknik. Fırat Üniv. Fen-Ed. Fak. Yayın. Bot. No. 1, stanbul.

Aniszewski, T., A.L. Karttunen and H. Hyvarinen. 2006. Structure of Phaseolus lunatus testa at its central point. Acta Biologica Cracoviensia Ser. Botanica 48(1): 69-76.

Asilbekova, D.T. 2004. Lipids of Thermopsis alterniflora bean seeds and shells. Chemistry of natural compounds 40(6): 532-534

Baytop, A. 1991. Farmasötik Botanik Ders Kitabi. stanbul Üniv. Yay. No: 3637, Ecz. Fak. Yay. No: 58, stanbul (in Turkish).

Biernaskie, J.M. and R.V. Cartar. 2004. Variation in rate of nectar production sepends on floral display size: A pollinator manipulation hypothesis. Functional Ecology 18(1): 125-129.

Chen, C.J., M.G. Mendenhall and B.L. Turner. 1994. Taxonomy of Thermopsis (Fabaceae) in North America. Ann. Missouri Bot. Garden 81(4): 714-742.

Corner, E.J.H. 1951. The Leguminous Seed. Phytomorphology 1: 117-150.

Corner, E.J.H. 1976. The Seeds of Dicotyledons. Vol. 1-2, Cambridge University Press, Cambridge, UK. 
Crow, E., C.H. Stirton and D.F. Cutler. 1997. Leaf anatomy of the genus Psoralea sensu Stricto (Psoraleeae, Papilionoideae, Leguminosae). Bot. J. Linn. Soc. 124: 155-182.

Davis, P.H. 1969. Flora of Turkey and the East Aegean Islands. Vol. 3, Edinburgh University Press, Edinburgh, U.K.

Davis, P.H., R.R. Mill and T. Kit. 1988. Flora of Turkey and the East Aegean Islands. Vol. 10, Edinburg University Press, Edinburg.

Delucia, E.H., K. Nelson, T.C. Vogelmann and W.K. Smith. 1996. Contribution of intercellular reflectance to photosynthesis in shade leaves. Plant, Cell and Environment 19(2): 159-170.

Doyle, J.J., J.A. Chappill, D.C. Bailey and T. Kajita. 2000. Towards a comprehensive phlylogeny of legumes: evidence from RBLC sequences and non-molecular data. In: Advances in Legume Systematics, P.S. Herendeen and A. Bruneau (Eds.). Royal Botanic Garden, Kew, pp 1-20.

Kit, T., M. Vural and M. Küçüködük. 1983. An unusual new Thermopsis from Turkey. Notes RBG Edinb. 40(3): 515-518.

Kotenko, L.D., A.U. Mamatkhanov, M.T. Turakhozhaev and M.P. Yuldashev. 2001. Quantitative analysis of flavonoids in the total preparation of Thermopsis alterniflora. Chemistry Natr. Compounds 37(2): 137-139.

Li, C.T. 1997. Wild legumes resources and their utilization in alpine meadow of Tianzhou area, Gansu. Grassland of China 1: 23-24, 28.

Lockhart, B.E.L. 2005. Three previously unrecorded viral diseases of Astilbe, Fuschia and Thermopsis species in Minnesota. Plant Disease 89(7): 775.

Martin, G., D.A. Myers and T.C. Vogelmann. 1991. Characterization of plant epidermal lens effects by a surface replica technique. J. Exp. Bot. 42(238): 581-587.

Mcgrath-Hill, C.A. and I.M. Vicas. 1997. Case series of Thermopsis exposures. J. Toxicology-Clinical Toxicol. 35(6): 659-65.

Myers, D.A., D.N. Jordan and T.C. Vogelmann. 1997. Inclination of sun and shade leaves influences chloroplast light harvesting and utilization. Physiol. Plantarum 99(3): 395-404.

Oliveira, D.M.T. and E.A.S. Paiva. 2005. Anatomy and ontogeny of Pterodon emarginatus (Fabaceae: Faboideae) Seed. Braz. J. Biol. 65(3): 483-494.

Pereira-Netto, A.B. De, A.C. Gabriele and H.S. Pinto. 1999. Aspects of leaf anatomy of Kudzu (Pueraria lobata, Leguminosae-Faboideae) related to water and energy balance. Pesq. Agropec. Bras., Brasilia, 34(8): 1361-1365.

Rahman, A.U., A. Pervin, M.I. Choudhary, N. Hasan and B. Sener. 1991. Sophazrine - a novel quinolizidine alkaloid from Sophora griffithii. J. Nat. Products 54(4): 929-935.

Talavera, S. and P. Gibbs. 1997. Cytisus purgans Auct. (Leguminosae-Papilionideae) comprises four distinct species. Bot. J. Linn. Soc. 125: 331-342.

Vogelmann, T.C. and G. Martin. 1993. The functional significance of palisade tissue penetration of directional versus diffuselight. Plant Cell and Environ. 16(1): 65-72.

Wang, H.C., H. Sun, J.A. Compton and J.B. Yang. 2006. A phylogeny of Thermopsideae (Leguminosae: Papilionoideae) inferred from nuclear ribosomal internal transcribed spacer (ITS) sequences. Bot. J. Linn. Soc. 151(3): 365-373.

Werker, E. 1997. Seed Anatomy. In: Encyclopedia Plant Anatomy, Carlquist S, Cutler DE, Fink S, Ozenda P, Roth I, and Ziegler H (Eds.), 10(3): 1-424 Gebrüder Borntraeger, Berlin.

Yiotis, C., Y. Manetas and G.K. Psaras. 2006. Leaf and stem anatomy of the drought deciduous mediterranean shrub Calicotome villosa (Poiret) Link. (Leguminosae). Flora 210: 102-107.

Zhang, Z. and S. Liu. 1996. Studies on wild legume forage resources in East Qinghai-Tibet alpine grassland. rangelands in a sustainable biosphere. Proc. Fifth Intl. Rangeland Congress, Salt Lake City, Utah, USA, 23-28 July, 1995, Vol. 1: 634-635.

(Manuscript received on 20 February, 2007; revised on 13 October, 2008) 